\title{
Understanding the precursor frequencies of HIV-1 specific CD4+ T cells in seronegative donors
}

\author{
SL Campion ${ }^{1 *}$, T Brodie $^{2}$, A Rossetti ${ }^{2}$, N Goonetilleke ${ }^{1}$, F Sallusto $^{2}$, A McMichael ${ }^{1}$ \\ From AIDS Vaccine 2012 \\ Boston, MA, USA. 9-12 September 2012
}

\section{Background}

HIV-1 specific $\mathrm{T}$ cell responses are detectable amongst a proportion of HIV-1 exposed, seronegative individuals. Previous studies from our group have demonstrated these responses are predominately mediated by $\mathrm{CD} 4+\mathrm{T}$ cells and can be mapped and titrated at the peptide level. Curiously, approximately 1 in 4 HIV-1 un-exposed seronegative donors also have demonstrable HIV-1 specific T cell responses. This observation raises a number of questions regarding the ontogeny of pre-existing HIV-1 specific $\mathrm{T}$ cells and their potential role in the acquisition of HIV-1.

\section{Methods}

A highly sensitive $\mathrm{T}$ cell library method was used to screen the naïve, central and effector memory CD4+ T cell subsets from 10 healthy, HIV-1 seronegative, leukapharesis donors. 192 cell lines per subset were screened against pools of overlapping 18 mer peptides, spanning the entire HIV-1 proteome and proliferative responses quantified using tritiated thymidine incorporation.

\section{Results}

HIV-1 specific CD4+ T cell response were detectable within the CD4+ $\mathrm{T}$ cell memory compartments of all 10 subjects tested, albeit at low frequency. HIV-1 specific CD4+ T cell responses spanned the entire HIV-1 proteome and were typically of low avidity. There was considerable variability between donors both in the proteins recognized and precursor frequencies of HIV-1 specific $\mathrm{T}$ cell responses. However, across all subsets tested CD4+ $\mathrm{T}$ cells specific for HIV-1 envelope appeared to exist at the highest precursor frequency, with Pol seemingly the least frequently targeted.

'University Of Oxford, Oxford, UK

Full list of author information is available at the end of the article

\section{Conclusion}

We show HIV-1 specific CD4+ T cells to be detectable within the memory compartment of all 10 donors tested. In the absence of known prior exposure to HIV-1 these observations are indicative of low level cross reactivity within the immune system. The use of the $\mathrm{T}$ cell library technique to interrogate the naïve and memory precursor frequencies of HIV-1 specific T cells should prove beneficial in the design of novel therapeutic vaccines.

\section{Author details}

'University Of Oxford, Oxford, UK. ${ }^{2}$ RRB, Bellinzona, Switzerland.

Published: 13 September 2012

doi:10.1186/1742-4690-9-S2-P289

Cite this article as: Campion et al:: Understanding the precursor

frequencies of HIV-1 specific CD4+ T cells in seronegative donors. Retrovirology 2012 9(Suppl 2):P289.

Submit your next manuscript to BioMed Central and take full advantage of:

- Convenient online submission

- Thorough peer review

- No space constraints or color figure charges

- Immediate publication on acceptance

- Inclusion in PubMed, CAS, Scopus and Google Scholar

- Research which is freely available for redistribution

\section{Ciomed Central}

